https://artnodes.uoc.edu

\title{
Discourses on artistic research in Flanders: non-scholarly perspectives on research in the arts
}

\author{
Florian Vanlee \\ Vrije Universiteit Brussel \\ Date of submission: September 2020 \\ Accepted in: November 2020 \\ Published in: January 2021
}

\section{Recommended citation}

Vanlee, Florian. 2021. «Discourses on artistic research in Flanders: non-scholarly perspectives on research in the arts». In: Benítez, Laura; Berger, Erich (coord.) «Arts in the time of pandemic». Artnodes, no. 27: 1-10. UOC. [Accessed: dd/mm/yy]. http://doi.org/10.7238/a.v0i27.374374

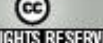

\begin{abstract}
The research presented in this paper collects and analyses a set of documents disseminating discourse on artistic research in Flanders - the Northern, Dutch-speaking region of Belgium. In doing so, it identifies hegemonic constructions structuring the (im)possibility of fostering fruitful interlinkages between the often-dichotomised notions of 'art' and 'science'. Hinged on the officialisation of the first Flemish doctoral degrees in the arts, the study points to earlier, 'inclusive' discourses on artistic research that allowed articulating a variety of activities and outcomes as 'research'. The introduction of the PhD gave way to 'exclusive' discourses that restrict artistic research to the higher arts education context. Notably, these 'exclusive discourses' - often disseminated by higher art educators - are expressively critical of the research agenda. Highlighting its artificial origins in the Bologna Process, artistic research is normatively constructed as an infringement on the arts' autonomy. Its potential is not denied altogether, however, but only touched upon in cryptonormative terms that reject current conditions without addressing what it should or could be.
\end{abstract}




\section{artnodes}

https://artnodes.uoc.edu

Discourses on artistic research in Flanders: non-scholarly perspectives on research in the arts

\section{Keywords}

artistic research, higher arts education, research in the arts, arts-based research, Flanders

\section{Tratados sobre investigación artística en Flandes: perspectivas no académicas sobre la investigación en las artes}

\section{Resumen}

En la investigación que se presenta en este artículo se recopila y se analiza un conjunto de documentos con los que se divulga un tratado sobre la investigación artística en Flandes -la región al norte de Bélgica, donde se habla neerlandés-. Para ello, se identifican construcciones hegemónicas que estructuran la (im)posibilidad de fomentar vínculos fructíferos entre los conceptos de arte y ciencia, dicotomizados con frecuencia. En el estudio, que se basa en la oficialización de los primeros títulos flamencos de doctorado en artes, se destacan tratados anteriores «inclusivos» sobre la investigación artística que permitieron estructurar una gran variedad de actividades y criterios como «investigación». La introducción del doctorado dio paso a tratados «exclusivos» que restringen la investigación artística en el ámbito de la educación artística superior. Estos «tratados exclusivos» -habitualmente divulgados por docentes de estudios superiores de arte-son, en particular, expresivamente críticos con los verdaderos objetivos de investigación. La investigación artística, que hay que recordar que sus orígenes son artificiales porque surgen en el Plan Bolonia, se configura normativamente como una violación a la autonomía de las artes. Sin embargo, su potencial no se rechaza por completo, sino que solo se menciona de pasada en términos criptonormativos que rechazan las condiciones actuales sin abordar lo que debería o podría ser.

\section{Palabras clave}

investigación artística, Educación Artística Superior, investigación en las artes, arte a través de la investigación, Flandes

\section{Introduction}

In Western Europe, formal interaction between 'the arts' and 'research' commenced with the 1999 onset of the Bologna Process - a supranational effort to harmonise the fragmented European higher education sector (Lesage, 2009; Hellström, 2010; Wesseling, 2011; Biggs \& Karlsson, 2011 Borgdorff, 2012). Artistic research ${ }^{1}$ is therefore a slightly artificial construct in many Western European countries (see Author 001 et al., 2019), lacking the historical tradition of 'traditional' research practices (Hannula, 2009: 110-111). Its artificiality notwithstanding, it is now institutional and material reality. As a nascent field, it at once operates by and reconfigures its disciplinary boundaries. Scholars working on artistic research (e.g. Hannula, 2009; Borgdorff, 2012) and artists/researchers whose practice situates their work in artistic research (e.g. Impett, 2017; De Assis \& Giudici, 2017) recognise this dimension of generative productivity. Artistic research continually (re)negotiates relations between artistic outcomes and meta-reflexive scholarship. As Hannula (2009) notes, artistic research - both as practice and object of study - is a complex discursive formation generating a 'radical necessity for continuously and coherently taking part in the making and shaping of concepts' (110-111). Consequently, authors like Hellström (2010: 314) or Biggs and Karlsson (2011: 410) call for disciplinary metadiscourses to define the 'aims and objectives of research' (Biggs \& Karlsson, ibid: 414).

Acknowledging scholarship on artistic research's discursive productivity (e.g. Jewesbury, 2009; Sheikh, 2009; Mäkelä et al., 2011; Gielen, 2013) and calls for metareflection (e.g. Hellström, 2010; Biggs \& Karlsson, 2011; Vanlee \& Ysebaert, 2019). invite addressing processes that underlie and constitute artistic research. Rather than discussing epistemology (e.g. Mäkelä et al., 2011) or methodology (e.g. Eisner, 1981; Blom et al., 2011; Hannula et al., 2014), this centralises the terms and premises of the discussion itself. By emphasising this ambition, this paper is both a case study and a methodological contribution. First, it maps out public debate on

1. For clarity, this paper consistently employs 'artistic research'. Concepts like 'research in the arts' or 'arts-based research' were included as queries during data collection. 


\section{artnodes}

https://artnodes.uoc.edu

Discourses on artistic research in Flanders: non-scholarly perspectives on research in the arts

artistic research in Flanders - the Northern, Dutch-speaking region of Belgium. Combining a scoping study (see Levac et al., 2010; Anderson et al., 2008) with content analysis (see Elo \& Kyngäs, 2008; Mayring, 2014; Krippendorff, 2018), it charts the timeline of Flemish discourse on artistic research (1), identifies dominant actors (2), demonstrates its thematic contexts (3) and shows authoritative subdiscourses (4). Discourse analysis (see Fairclough, 2013) further explores the latter findings, critically examining hegemonic constructions of artistic research in Flanders. This points to tensions between overt and covert normative claims (see Worsnip, 2017; Abbott, 2018; Sass, 2018) on the subject - explicit in their dismissal of the perceived ideology of the Bologna Process but implicit in their recognition of artistic research's potential. As a methodological contribution, it emphasises the value of social sciences methods to a 'field in construction'. Its combination of descriptive research with critical, interpretative analysis offers a modality for scholars to approach the generative productivity of artistic research situated outside of traditional scholarly networks.

\section{Collecting and analysing flemish discourses on artistic research}

Literature on artistic research has focused on theory and methodology in their relation to the arts as a mode of knowledge production (e.g. Mäkelä et al., 2011; Borgdorff, 2012), the institutionalisation of artistic research (e.g. Jewesbury, 2009; Gielen, 2013) and frictions brought by the introduction of the arts to the university sector (e.g. Hellström, 2010; Lewandowska \& Stano, 2018). The potential of collecting and analysing larger bodies of data notwith-standing (e.g. Schwab, 2012; Vanlee \& Ysebaert, 2019), sources demonstrate a preference for small-scale or theoretical approaches. By focusing on the 'Flemish public debate on artistic research', this paper is less concerned with Flemish artistic research proper - like practitioners or outcomes - and more with (public) claims about it. This is a reduction of its inherent complexity, but exploring one particular dimension to a discursive system generates valuable insights if properly delineated (Keller, 2011). Given the amorphous nature of artistic research in Flanders - lacking robust definition (see Ysebaert \& Martens, 2018), focusing on discourse about artistic research elucidates differing perspectives and conceptualisations at play.

Scoping studies (e.g. Levac et al., 2010; Anderson et al., 2008) seem an odd fit here, but provide robust methods to locate 'public discourse on artistic research in Flanders' and create a sample of texts for analysis. An explorative technique to 'map relevant literature in the field of interest' (Arksey \& 0'Malley, 2005: 22), they feature iterative steps of identification and collection - typically initiated by broad research question or keyword (Levac et al., 2010). Here, this was initiated by querying 'artistic research' in scholarly databases (Web of Science [WoS] and JSTOR), identifying additional keywords - like research in the arts and arts-based research. Location-based filters ${ }^{2}$ singled out 11 Flemish publications. These explicitly positioned themselves in or as artistic research - situating them outside of the present study's scope, and did not constitute a saturated data set. Keywords were therefore queried ${ }^{3}$ in FRIS [Flanders Research Information Space] - the database collecting Flemish research output, including from popular sources. This indicated that relevant non-peer reviewed publications were either published in De Witte Raaf [DWR], Rekto:Verso [RV] - two journals dedicated to arts and culture - or were contributions to newspapers. Having located the predominant outlets for Flemish discourses on artistic research, keywords were finally used to collect all articles mentioning at least one of the keywords between January 1st 1999 to December 31 st $2018^{4}$ in these outlets. For De Witte Raaf and Rekto:Verso, the journal's websites allowed finding and exporting articles, whereas Go-Press - an online database of the Flemish written press - provided the material from Flemish newspapers with national circulation ${ }^{5}$.

After data cleaning and disambiguation, this produced a set of 181 articles -45 published by DWR, 26 by RV and GoPress accounts for 110 texts. Metadata - title, publication, data and (if applicable) author - were coded onto individual entries for descriptive analysis, which were subsequently imported in NVivo, a qualitative data analysis software package. This facilitated exploring articles' content inductively (see Elo \& Kyngäs, 2008), resulting in thematic clusters reflecting the dominant subject matter of the texts and in an overview of key terms' frequencies. Discursive clusters thus emerged from document patterns, not from theoretical perspectives or existing empirical findings (Mayring, 2014: 79). Relating the content analysis' findings to metadata identified articles with artistic research as their primary interest - likely offering insights into dominant discourses on the subject. To interpret and deconstruct these dominant meanings and conceptualisations of artistic research in Flanders, this smaller set - consisting of 48 DWR and RV articles - was subjected to critical discourse analysis (Fairclough, 2013). Here, the aim was to understand implicit dispositions and assumptions shaping these articulations (Keller, 2011). Shifting to a deductive register, previously discovered

2. This happened using the dedicated tool in WoS (i.e. 'Filter by Region') and by adding 'Flemish', 'Flanders', 'Belgium' and 'Belgian' to queries in JSTOR.

3. Because FRIS also includes publications in Dutch, keywords were entered in Dutch too: 'artistiek onderzoek', 'onderzoek in de kunsten' and 'onderzoekskunst' were used.

4. This corresponds to the initiation of the Bologna Process (i.e. 1999) to the present.

5. These are: De Morgen, De Standaard, De Tijd, Het Nieuwsblad and Het Laatste Nieuws. 


\section{artnodes}

https://artnodes.uoc.edu

patterns are related to critical theoretical insights - focusing on normative convictions structuring dominant Flemish discourses on artistic research.

\section{Mapping discourses on artistic research in flanders}

Discourse on rapprochements between 'the arts' and 'research' has a relatively long history in the US (see Sullivan, 2006), the UK (see Jewesbury, 2009) and Nordic countries (see Hannula, 2008), but is inherently connected to the Bologna Process in Flanders - and the first doctoral graduations in the arts in the 2006-2007 academic year (see Lesage, 2009). Since 1999, Flemish newspapers did address 'research' in the context of the arts before the academisation of Flemish higher arts education (see Graph 1). 44 of 51 newspaper articles published before 2006 do so without referring to higher art education, pointing instead to 'research' as an ambition of art institutions $(n=21)$, as a quality of artworks or exhibitions $(n=15)$ or as a practice of artists or collectives $(\mathrm{n}=8)$ (see Graph 2). The 5 articles published in De Witte Raafbefore 2006 (see Graph 1) address research in similar contexts, articulating it to topics other than education.

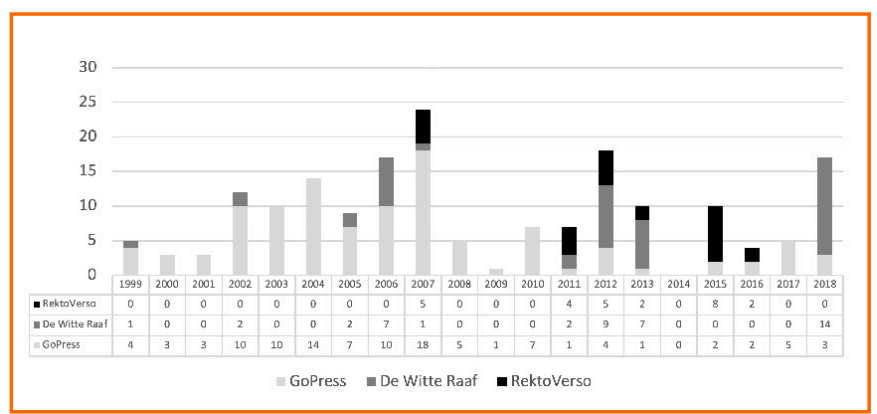

Graph 1: Distribution of documents per year and publication outlet ${ }^{6}(\mathrm{~N}=181)$

The granting of the first doctoral titles in 2006-2007 generated unprecedented attention for artistic research, accounting for roughly one quarter of the articles in the data set $(23.04 \%, N=181$, see Graph 1). It also shifted where Flemish discourses on artistic research were located. Whereas newspaper articles make up the bulk of material until 2007 (81.5\%, n=97, see Graph 1), De Witte Raafand Rekto:Verso are primary outlets in the $2008-2018$ period $(63.1 \%, n=84$, see Graph 1). 'Mainstream' interest in the subject wanes after peaking in 2006-2007 - brought by the graduation of the first Flemish doctoral candidates in the arts - but 'niche' attention in De Witte Raaf and Rekto:Verso finds its origins there, sporadically resurfacing until today (see Graph 1).
These differences cut across thematic contexts too. Before the officiation of the doctorate in the arts, newspaper reporting freely articulated research qualities to non-educational artistic practices. Where 21 newspaper articles before 2006 characterise 'research' as something non-educational institutions engage in, for instance, only 5 do so afterwards (see Graph 2, $n=26$ ). Similar shifts emerge in popular references to 'artistic research' about works of arts or artists' oeuvres (see Graph 2). In De Witte Raafand Rekto:Verso, conversely, conceptualisations of artistic research are more restricted. Instead of describing artworks or the practices of artists or institutions as (the product of ' 'research', it is predominantly mentioned in texts discussing the academisation of higher arts education (i.e. Arts Education \& Integration) or dealing with the doctorate in the arts (i.e. Doctorate and Artistic research) (see Graph 2).

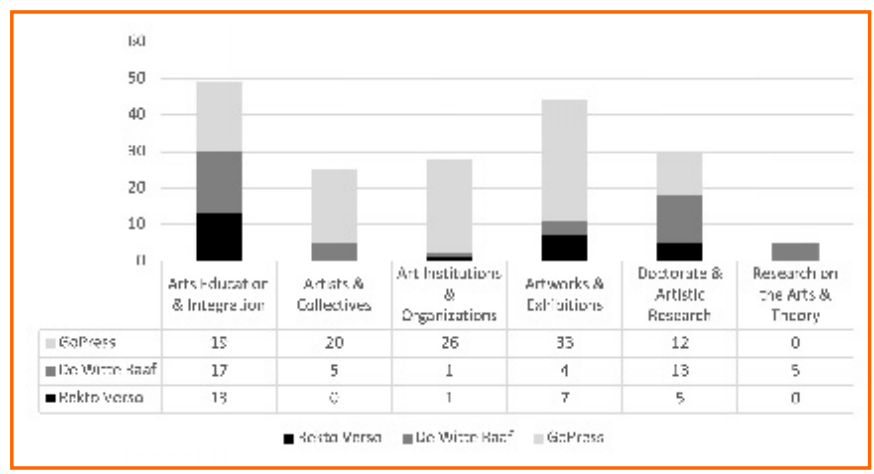

Graph 2: Distribution of documents over dominant subject clusters and publication outlet $(\mathrm{N}=181)$

Articles focused on Arts Education \& Integration or Doctorate \& Artistic Research discuss artistic research more thoroughly too - especially in De Witte Raaf and Rekto:Verso (see Graph 3). Newspaper reporting generally mentions 'artistic research', 'research in the arts' or 'arts-based research' in passing - rarely exceeding more than two references in articles that address anything other than the $\mathrm{PhD}$ in the arts or the idea of artistic research in particular (see Graph 3). Naturally, the publishing format of De Witte Raaf and Rekto:Verso differs from traditional newspaper reporting. Whereas the latter's focus lies on disseminating short texts, the former emphasise lengthy articles offering indepth perspectives on the artistic and cultural sector. It therefore makes little sense to overemphasise the higher average prevalence of references to one of the predetermined keywords in De Witte Raafor Rekto:Verso. Pointing to the contextual homogeneity wherein artistic research is discussed by De Witte Raaf and Rekto:Verso in relation to newspaper reporting is more telling here - particularly because references made by DWR and RV to

6. For clarity, the newspapers (see Footnote 5) are grouped under 'GoPress'. 


\section{artnodes}

https://artnodes.uoc.edu

Discourses on artistic research in Flanders: non-scholarly perspectives on research in the arts

artistic research about artworks, artists or art institutes originate before 2006 .

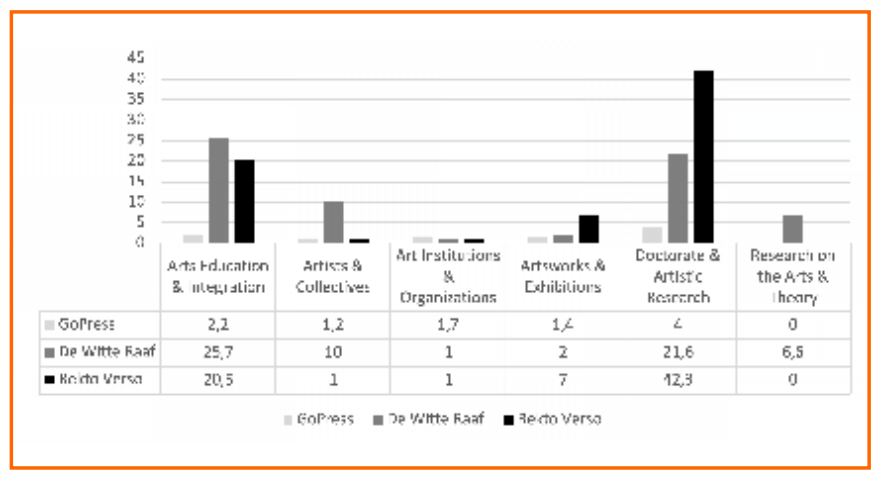

Graph 3: Average keyword frequency per article in dominant subject clusters and publication outlet $(\mathrm{N}=181)$

Formal differences between De Witte Raaf and Rekto:Verso and newspaper reporting likely account for the discrepancies in the type of individuals addressing artistic research in Flanders, or to whom it is articulated (see Graph 4). Where newspaper articles feature various perspectives - ranging from professional artists $(n=36)$, to curators and artistic leaders $(n=31)$ and academics or arts critics in general $(n=13)$ - most individuals discussing artistic research in De Witte Raaf and Rekto:Verso are either faculty members of Flemish institutes for higher art education, or academics and cultural critics associated with Schools of Arts as external teaching staff ${ }^{7}$ (see Graph 4). Policy makers involved in the introduction of the Bologna agreement to the Flemish higher education sector and individuals with an artistic research mandate are conspicuously absent from both newspaper reporting and specialty publications, but tend to voice their perspective in newspaper articles when this does happen ( $n=9$, see Graph 4).

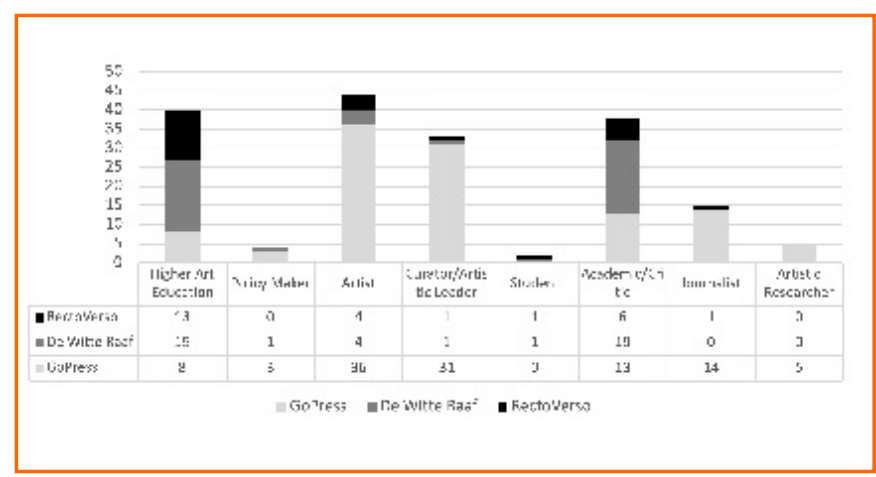

Graph 4: Distribution of individuals' professional background discussing artistic research $(\mathrm{N}=181)$

\section{Inclusive and exclusive flemish discourses on artistic research}

The foregoing warrants a distinction between inclusive (1) from exclusive (2) discourses on artistic research, separated by the institutionalisation of artistic research in 2006-2007. The first forward decidedly open characterisations of artistic research, exemplified by the variety of concepts it articulates and the diversity of actors appropriating it. The arts are generally framed and recognised as a process of knowledge production. Recognitions of discrepancies between 'scientific' and 'artistic' modes of inquiry notwithstanding, inclusive discourses allow artworks to be understood as 'research' or as resulting from it. It offers artists and organisations a vocabulary to articulate how their practices create new meaning, or artistically explore (social) reality. Such inclusive discourses parallel Eileen John's (2013) call to '[pursue] knowledge in conversation with art whether or not [there are] confident resolutions of the epistemic issues' (391). They recognise the possibility of artistic research without questioning the legitimacy of its epistemic claims, instead facilitating free appropriations 'research' in conjunction with 'the arts' to signify interventions in how certain phenomena are perceived. Insofar as the use of the word 'research' refers to particular qualities of artworks, artists or art organisations indicates an acceptance of an intellectual generativity (Mäkelä, 2007), the apparent irrelevance of subjects concerning higher art education, the doctorate in the arts or even discussions on the nature of artistic research itself (see Graph 2) testify to a willingness to accept the arts as a particular type of knowledge production dislodged from formal demands. Consequently, it is not inconceivable that shifts observed in the descriptive exploration were brought by the formalisation of artistic research in higher art education in the 2006-2007 academic year. The institutionalisation of artistic research obscures the research dimension of all artistic practice and renders it the privileged terrain of those institutions and mandated actors (Hannula, 2008; Jewesbury, 2009; Gielen, 2013). This elucidates the decreasing variety of thematic contexts wherein artistic research is addressed, and explains why art educators and adjacent academics become dominant sources of discourse on the subject.

It follows that the contemporary hegemony of exclusive discourses results not from intentional processes, but is a byproduct of the mandate given to institutes for higher art education. With the Schools of Arts - their formal Flemish designation - having become sanctioned sites for artistic inquiry, the legitimacy of other actors to appropriate 'research' decreased. The shift from inclusive to exclusive discourses on artistic research is therefore less the result of struggle for legitimacy in the social field of the arts and more of changing

7. Assigning professional background categories is ambiguous - faculty of IHAEs are often artists in their own right. In the context of this paper, however, it is crucial to distinguish artists outside of higher arts education from those employed at institutions (nominally) engaged in 'artistic research'. 


\section{artnodes}

https://artnodes.uoc.edu

Discourses on artistic research in Flanders: non-scholarly perspectives on research in the arts

external circumstances. The conditions regulating when, where and what research is shifted due to top-down processes in educational policy (Sheikh, 2009), and exclusive discourses reflect this new reality. With artistic research relegated to the Schools of Arts, the migration of discourse to De Witte Raafand Rekto:Verso- outlets acting as a forum for higher art education and the arts in general - is not surprising, nor is the dominance of art educators and adjacent academics (see Graph 4). This does not suggest, moreover, that these texts necessarily subscribe to the ideologies behind the political decision to bestow a responsibility to engage in artistic research upon the Schools of Arts. The fact that only once a policy maker was offered the opportunity to explicate his intentions - then minister of education Pascal Smet (Brams \& Pültau, 2013) - in a highly critical interview conducted by Schools of Arts faculty members suggests that resistance and critique are central to post-institutionalisation discourses on artistic research, notwithstanding their markedly exclusive conceptualisation. Fully understanding how exclusive discourses make sense of artistic research, and how they feed into its various apparitions in contemporary Flanders suppose indepth analyses, however. Therefore, the segments below critically deconstruct dominant characterisations and conceptualisations of artistic research articulated by coverage of De Witte Raaf and Rekto:Verso after the first doctorate in the arts had been obtained in 2006.

\section{Contemporary flemish discourse on artistic research}

That artistic research becomes relevant to De Witte Raaf and Rekto:Verso after the first PhD in the arts was awarded in 2006 (that of photographer Maarten Vanvolsem) is important to consider. Earlier Bologna effects evoked few reactions - notwithstanding that the bachelor's-master's structure had been implemented in 2004 (see Dittrich et al., 2004) and the first doctoral candidates had simultaneously enrolled. That the officialisation of this first title catalysed intensified discourse on artistic research in De Witte Raaf and Rekto:Verso illustrates that it is not so much focused on interplay of research and art (Borgdorff, 2012) but on what it symbolises in a wider sphere of art, education and knowledge. Tellingly, explicit references to domestic doctoral research are absent initially. The granting of the title made the doctorate in the arts a tangible reality in Flemish higher art education, explicating the implications of the particular structure wherein artistic research was institutionalised. In contrast to other contexts, Flemish institutes for higher art education retained a degree of autonomy in the post-Bologna landscape as standalone departments of university colleges ${ }^{8}$ (Lesage, 2009).
Aside from practical implications - like a separate model for funding allocation - this embedded PhD programmes in Schools of Arts, distinguishing them from regular university colleges (see Vanlee \& Ysebaert, 2019). Granting doctoral titles, however, remains a university monopoly, meaning that candidates have an internal artistic supervisor and an academic supervisor at the university their School of Arts is associated with (see Ysebaert \& Martens, 2018). Demonstrably, this inequity became tangible and problematic only when the title was officially granted. Art education 'was academized, instead of academizing itself (Tindemans, 2007), and the universities 'already occupying the terrain of knowledge production (what a coquettish word!) can now lay claim to artistic production (what a scandalous word!) too' (Lauwaert, 2006).

Flemish discourse on artistic research relates it to post-Bologna debates on higher art education. Artistic research is thus rarely discussed as an autonomous subject, but is articulated to issues revolving around the autonomy of art education and the arts. 'The institutional criteria of research in the arts might well contribute to a climate wherein artists will have to systematically account for the societal relevance of their work' (Van Winkel, 2006) and similar claims (e.g. Lauwaert, 2006; Pültau, 2012; Vanderbeeken, 2012) construct artistic research as symptomatic of nefarious socio-cultural trends. Academic critiques of the Bologna Process' neoliberalism (see Gielen, 2013) clearly resonate, positing that political interest in artistic research masks attempts to discipline the arts. It is perceived as an enforcement of managerial transparency on artists during their training, ensuring compliance with market demands: 'practical development and creativity must cater to the creative industry, artistic research being an economic investment that has to be reimbursed somehow' (Vanhaesebrouck, 2011). These articulations inhibit debate on artistic research's potential value for art education and the arts and connote it to encroachments on the arts' autonomy. Remarkably, scholarship on artistic research is discussed intensively by De Witte Raaf and Rekto:Verso. Works like that of Henk Borgdorff (2012), Janneke Wesseling (2011) or Mika Hannula, Juha Suoranta and Tere Vadén (2006) are critically reviewed (e.g. Pültau, 2012; Goossens, 2012; Lauwaert, 2006). Common in these reviews is a distrust of 'metaresearch'; 'academics' not only claim a monopoly on granting doctoral titles, but mandate themselves to shape artistic research from their privileged position too.

Post-2006 discourses on artistic research are expressively normative. Not in their conceptualisation of artistic research proper, but in its contextualisation. Overt denunciations of Bologna's impact on artistic training (e.g. Lauwaert, 2006; Tindemans, 2007; Vanhaesebrouck, 2011; Pültau, 2012; Vanderbeeken, 2012) and dismissals of scholarship on artistic research (e.g. Brams, 2006; Lauwaert,

8. In Flanders, University Colleges offer professional tertiary education, and are distinct from universities. 


\section{artnodes}

https://artnodes.uoc.edu

Discourses on artistic research in Flanders: non-scholarly perspectives on research in the arts

2006; Goossens, 2012) articulate it as the territory of higher art education and the arts in general. Insofar as contextual dimensions to artistic research are concerned, De Witte Raaf and Rekto:Verso consider detriments to an ideal situation - articulating a manifestly normative perspective (Worsnip, 2017). Though artistic research can be 'a space of possibilities to enhance research thinking and research practice'(Mäkelä et al., 2011: 9), Flemish discourse on the subject tends to focus not on possibilities, but critiques that such potentialities are stinted by policies that violate the arts' autonomy instead. Because peripheral dimensions to artistic research take centre stage, expressions on the shape it could or should take are cryptonormative at best. A reluctance to explicate underlying normative frameworks of evaluation (see Worsnip, 2017; Sass, 2018) is particularly prominent in the 2018 special issue of De Witte Raaf (i.e. Volume 196, November - December, 2018) discussing recently 'published' artistic research. Included reviews (e.g. Sels, 2018; Pint, 2018; Humblet, 2018) forward written dissertations as the sole 'legitimised' outcome of artistic research - that is, legitimate under conditions understood as iniquitous. Implicitly forwarding the stance that artistic research should be evaluated on its artistic merits, the texts offer scathing reviews of the dissertations' limited 'academic' merits. One suggests that the doctoral title obtained on grounds of the dissertation under discussion 'could only have been granted on the grounds of good intentions'(Van Gerrewey, 2018), whereas others gloss over artistic qualities altogether, characterising a project as 'design history' instead (Floré, 2018). Simply put, the reviews suggest that written dissertations are an inappropriate format to reflect artistic research. They refuse to explicate how artistic research should be practised or presented, however. In doing so, they reiterate normative denunciations of current conceptualisations of artistic research while simultaneously perpetuating cryptonormative allusions to the potential it might have in other circumstances.

\section{Conclusion}

Artistic research is an institutional and material reality - with increasing numbers of professional artists perfecting their practice through research. Discourse on artistic research is less interested in the particular forms such activities take, however, instead criticising the historical context of artistic research in Flanders and its current institutional framework. Admittedly, circumstances remain iniquitous, and universities' monopoly on granting doctoral titles offers disproportional influence in the conceptualisation of artistic research. Perceiving artistic research as a struggle to define legitimate forms of research is understandable, but is ultimately counterproductive. The emancipation of artistic research on the terms of higher art education and the arts in general will be predicated on frank, normative conceptualisations of what artistic research is or should be. This invites a discursive shift, whereby critical denunciations of peripheral dimensions to artistic research make way for debate on the particular potential such practices and artefacts might represent, not only to Flemish higher education, but to the arts in general too. To characterise the ambition of this paper only in Flemish terms would be a reduction too, however. Whereas scholarship on artistic research is flourishing, making important contributions to the ontology, epistemology and methodology of artistic research, its qualitative outlook cannot be allowed to obscure broader perspectives to be considered in the field too. The methods borrowed from the social sciences in this paper are admittedly coarse, and lack the interpretative depth offered by theoretical engagements with the subject. Their ability to map discussions on artistic research outside of the validated circuit of peer-reviewed publications, monographs and edited volumes do have the potential to point to the limits of scholarly discourses on the subject. The views and perspectives articulated by higher art educators and associated actors in popularising publications like De Witte Raaf and Rekto:Verso are likely to be closely related to the actual decisions taken and policies upheld at the Schools of Arts, and are crucial to consider.

\section{References}

Abbott, Andrew. "Varieties of normative inquiry: Moral alternatives to politicization in sociology." The American Sociologist 49, no. 2 (2018): 158-180. D0I: https://doi.org/10.1007/s12108-0179367-8

Anderson, Stuart, Pauline Allen, Stephen Peckham, and Nick Goodwin. "Asking the right questions: scoping studies in the commissioning of research on the organisation and delivery of health services." Health Research Policy Systems 6, no. 7 (2008). D0I: https://doi. org/10.1186/1478-4505-6-7

Arksey, Hilary, and Lisa 0'Malley. "Scoping studies: towards a methodological framework." International Journal of Social Research Methodology 8, no. 1 (2005): 19-32. D0l: https://doi. org/10.1080/1364557032000119616

Biggs, Michael, and Henrik Karlsson. "Evaluating quality in artistic research." In The Routledge companion to research in the arts, edited by Michael Biggs and Henrik Karlsson, 405-424. London: Routledge, 2011.

Blom, Diana, Dawn Bennett, and David Wright. "How artists working in academia view artistic practice as research: Implications for tertiary music education." International Journal of Music Education 29, no. 4 (2011): 359-373. Dol: https://doi. org/10.1177\%2F0255761411421088

Borgdorff, Henk. The conflict of the faculties: Perspectives on artistic research and academia. Leiden: Leiden University Press, 2012. 


\section{artnodes}

Brams, Koen, and Dirk Pültau. "Interview met Vlaams minister van onderwijs Pascal Smet over de integratie van de academische hogeschoolopleidingen in de universiteiten." De Witte Raaf, 165 (2013). https://www.dewitteraaf.be/artikel/detail/nl/3915

Crombez, Thomas. "Kunst als kennisproductie." Rekto:Verso, April 22 (2015). http://18.197.1.103/artikel/kunstals-kennisproductie

De Assis, Paulo, and Paolo Giudici, eds. Dark precursor: Deleuze and artistic research. Leuven: Leuven University Press, 2017. D0I: https://doi.org/10.2307/j.ctt21c4rxx

Dittrich, Karl, Mark Frederiks, and Marc Luwel. "The implementation of 'Bologna' in Flanders and the Netherlands." European Journal of Education 39, no. 3 (2004): 299-316. D0I: https://doi. org/10.1111/j.1465-3435.2004.00185.x

Eisner, Elliot W. "On the differences between scientific and artistic approaches to qualitative research." Educational Researcher 10, no. 4 (1981):5-9. DOI: https://doi.org/10.3102\%2F0013189X010004005

Elo, Satu, and Helvi Kyngäs. "The qualitative content analysis process." Journal of Advanced Nursing 62, no. 1 (2008): 107-115. DOI: https://doi.org/10.1111/j.1365-2648.2007.04569.x

Fairclough, Norman. Critical discourse analysis: The critical study of language. London: Routledge, 2013. DOI: https://doi. org/10.4324/9781315834368

Floré, Fredie. "Elegante jachtgeweren.” De Witte Raaf, 196 (2018). https://www.dewitteraaf.be/artikel/detail/nl/4578

Gielen, Pascal. "Artistic praxis and the neoliberalization of the educational space." Journal of Aesthetic Education 47, no. 1 (2013): 58-71. DOI: https://doi.org/10.5406/jaesteduc.47.1.0058

Hannula, Mika. "Catch me if you can: Chances and challenges of artistic research." Arts \& Research: A Journal of Ideas, Contexts and Methods 2, no. 2 (2009): 109-129.

Hellström, Tomas. "Evaluation of artistic research." Research EvaIuation 19, no. 5 (2010): 306-316. Dol: https://doi.org/10.3152 /095820210X12809191250807

Humblet, Steven. "Een sensoriële machine." De Witte Raaf, 196 (2018). https://www.dewitteraaf.be/artikel/detail/nl/4563

Impett, Jonathan, ed. Artistic research in music: Discipline and resistance. Leuven: Leuven University Press, 2017.

Jewesbury, Daniel. "Some problems with 'research' in UK Fine Art institutions." Art \& Research 2, no. 2 (2009): 1-3.

John, Eileen. "Art and knowledge." In The Routledge Companion to Aesthetics, edited by Berys Gaut and Dominic Lopes, 384-393. London: Routledge, 2013.

Keller, Reiner. The sociology of knowledge approach to discourse (SKAD). Human Studies 34, no. 1 (2011): 43-65. D0l: https://doi. org/10.1007/s10746-011-9175-z

Krippendorff, Klaus. Content analysis: An introduction to its methodology. Thousand Oaks, CA: Sage, 2018.

Lauwaert, Dirk. "Moi, j'aime les professeurs (op een melodie van Offenbach)." De Witte Raaf122 (2006). https://www.dewitteraaf. be/artikel/detail/nl/3091

Lesage, Dieter. "Who's afraid of artistic research? On measuring artistic research output." Art \& Research 2, no. 2 (2009): 1-10.

Levac, Danielle, Heather Colquhoun, and Kelly 0'Brien. "Scoping studies: advancing the methodology." Implementation Science 5, no. 1 (2010): 69-78. D0l: https://doi.org/10.1186/1748-5908-5-69

Lewandowska, Kamila, and Pawel M. Stano. "Evaluation of research in the arts: Evidence from Poland." Research Evaluation 27, no. 4 (2018): 323-334. D0l: https://doi.org/10.1093/reseval/rvy021

Mäkelä, Maarit. "Knowing through making: The role of the artefact in practice-led research." Knowledge, Technology \& Policy 20, no. 3 (2007): 157-163. D0I: https://doi.org/10.1007/s12130-007-9028-2

Mäkelä, Maarit, Nithikul Nimkulrat, D. P. Dash, and Francois-X. Nsenga. "On reflecting and making in artistic research." Journal of Research Practice 7, no. 1 (2011): 1-12.

Mayring, Philipp. Qualitative content analysis: Theoretical foundation, basic procedures and software solution. Leibniz: Beltz, 2014.

Pint, Kris. “Gevecht met een genre.” De Witte Raaf196 (2018). https:// www.dewitteraaf.be/artikel/detail/nl/4577

Pültau, Dirk. "Alle macht aan de universiteiten." De Witte Raaf 159 (2012). https://www.dewitteraaf.be/artikel/detail/nl/3825

Sass, Jensen. "The cryptonormative swamp: A response to Abbott's 'Varieties of normative inquiry'." The American Sociologist 49, no. 3 (2018): 448-455. D0l: https://doi.org/10.1007/s12108-018-9383-3

Schwab, Michael. "The research catalogue:A model for dissertations and theses." In The SAGE handbook of dissertations and theses, edited by Richard Andrews, Erik Borg, Stephen Boyd Davis, Myrrh Domingo and Jude England, 339-354. Thousand Oaks, CA: Sage, 2012.

Sels, Koen. "Het ware leven." De Witte Raaf 196 (2018). https://www. dewitteraaf.be/artikel/detail/nl/4582

Sheikh, Simon. "Objects of study or commodification of knowledge? Remarks on artistic research." Art \& Research 2, no. 2 (2009): 1-8.

Sullivan, Graeme. "Research acts in art practice." Studies in Art Education 48, no. 1 (2006): 19-35. DOl: https://doi.org/10.108 0/00393541.2006.11650497

Tindemans, Klaas. "Kunst is kennis: Is een doctoraat in de kunsten denkbaar?" Rekto:Verso, April 12 (2017). https://www.rektoverso. be/artikel/kunst-kennis

Vanderbeeken, Robert. "Stem niet voor de vermarkting van cultuur." Rekto:Verso, October 8 (2012). https://www.rektoverso.be/artikel/ stem-niet-voor-de-vermarkting-van-cultuur

Van Gerrewey, Christophe. "De ene ander is de andere niet." De Witte Raaf 196 (2018). https://www.dewitteraaf.be/artikel/detail/ $\mathrm{nl} / 4562$

Vanlee, Florian, and Walter Ysebaert. "Disclosing and evaluating artistic research." Journal of Data and Information Science 4, no. 3 (2019): 35-54. D0l: https://doi.org/10.2478/jdis-2019-0014

Wesseling, Janneke, ed. See it again, say it again: The artist as researcher. Amsterdam: Valiz, 2011. 


\section{artnodes}

https://artnodes.uoc.edu

Discourses on artistic research in Flanders: non-scholarly perspectives on research in the arts

Worsnip, Alex. Cryptonormative judgments. European Journal of Philosophy 25, no. 1 (2017): 3-24. D0l: https://doi.org/10.1111/ ejop. 12208
Ysebaert, Walter, and Birgit Martens. "The ECOOM-VUB stakeholderdriven evaluation design for art and design research outcomes." In Evaluating art and design research: Reflections, evaluation practices and research presentations, edited by Walter Ysebaert and Birgit Martens, 93-109. Brussels: VUB Press, 2018. 


\section{artnodes}

https://artnodes.uoc.edu

Discourses on artistic research in Flanders: non-scholarly perspectives on research in the arts

\section{CV}

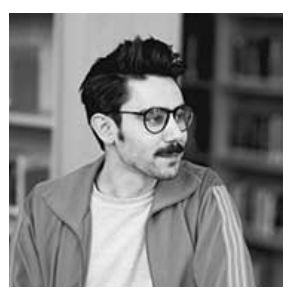

\section{Florian Vanlee}

Vrije Universiteit Brussel

florian.hendrik.j.vanlee@vub.be

Dr. Florian Vanlee holds a BA in Stage and Media Arts from Ghent University and a MA in Film Studies and Visual Culture from Antwerp University. Since March 2015, he worked on a FW0-funded PhD project titled 'Sexual Diversity on the Small Screen: a qualitative research into the representation of and public debate about LGBTs in Flemish television fiction series'. Using a multi-methodological approach, his research analyzed the ways in which sexual and gender diversity are constructed in Flemish television fiction, how LGBT+ characters and narratives are negotiated by television professionals and how queer television theory relates to smaller national contexts. After obtaining his doctoral title, he started working as a postdoctoral researcher for ECOOM Brussels, with a focus on artistic research and its evaluation in the Flemish higher education context. Since September 2020, he acts as editor-in-chief for DiGeSt: Journal for Diversity and gender Studies. 